\title{
Russian Arctic Petroleum Resources
}

\author{
A. Zolotukhin and V. Gavrilov \\ Gubkin Russian State University of Oil and Gas, GSP-1, Leninsky prospekt, 65, 119991, Moscow - Russia \\ e-mail: zolotukhin.a@gubkin.ru - gavrilov@gubkin.ru
}

\begin{abstract}
Résumé - Ressources pétrolières de l'Arctique russe - Le plateau continental arctique est considéré comme la zone comportant le potentiel inexploré le plus important tant en termes d'huile et de gaz qu'en ressources en hydrocarbures non conventionnels tels que les hydrates de gaz. En dépit d'une vision courante selon laquelle l'Arctique possède des ressources abondantes en hydrocarbures, des débats se poursuivent sur le potentiel énergétique de cette région. Les lignes directrices de telles discussions reposent sur la géopolitique, les questions environnementales, l'évaluation et la délimitation des ressources arctiques, la technologie disponible pour le succès de leur exploitation et les perspectives d'évolution de la demande en énergie.
\end{abstract}

La partie russe est reconnue comme étant la plus importante concernant les ressources en huile et gaz des nations arctiques. Toutefois, le manque d'informations et de données géologiques disponibles engendre une incertitude sur le rôle futur de l'Arctique russe comme principal fournisseur d'énergie dans la seconde partie du XXI ${ }^{\mathrm{e}}$ siècle. Une incertitude supplémentaire repose sur le rythme auquel la production provenant des zones nordiques incluant l'Arctique sera activée - que ce soit du fait de la politique nationale, du développement d'infrastructures ou d'investissement par l'état et les compagnies pétrolières. Ces zones englobent celles où une exploitation a déjà été entamée (au large de l'île Sakhaline, dans le Timan Péchora du nord) et celles en attente d'une implication à venir, comme les mers de Barents et de Péchora, la Sibérie orientale, la péninsule de Yamal, la mer de Kara et le Kamchatka.

Les niveaux de production offshore vont probablement être très importants pour la Russie à moyen et long terme, particulièrement du fait que la plupart (sinon la totalité) de la production sera exportée et, ce faisant, ouvrira des portes vers de nouveaux marchés. De cette manière, la production offshore introduira une composante nouvelle et très significative à la stratégie d'exportation de la Russie. Toutefois, une implication active des ressources arctiques russes dans le processus global de fourniture d'énergie exige une analyse détaillée et une compréhension claire du potentiel du marché du gaz et de l'huile russes (volumes demandés, calendrier d'exécution, voies de transports); elle exige aussi une attention soutenue de la part du gouvernement sur les points les plus importants qui devront être mis en place, tels que des normes et directives nationales pour l'exploitation des ressources arctiques, une législation stable, transparente et sans surprise à titre de condition préalable nécessaire à des investissements massifs dans l'exploration et la production et, notamment, une implication active de compagnies étrangères dans l'exploitation des ressources arctiques qui pourrait apporter en même temps que les investissements une compétence et une expérience indispensables, une technologie disponible et des principes d'Hygiène, Sécurité et Environnement (HSE).

L'exploitation de champs d'huile et de gaz dans les mers arctiques situées à quelques centaines de kilomètres des côtes constitue selon l'opinion des experts le projet le plus difficile au monde. Sans une coopération internationale, une coordination de toutes les activités et l'utilisation de technologies modernes et éprouvées pour la production et le transport d'hydrocarbures, des outils de sécurité et de protection environnementale efficaces, la réalisation d'un tel projet serait remise en question. 


\begin{abstract}
Russian Arctic Petroleum Resources - The Arctic continental shelf is believed to be the area with the highest unexplored potential for oil and gas as well as for unconventional hydrocarbon resources such as gas hydrates. Despite a common view that the Arctic has plentiful of hydrocarbon resources, there are ongoing debates regarding the potential of this region as a future energy supply base. Driving forces for such discussions are geopolitics, environmental concern, assessment and delineation of Arctic resources, technology available for their successful development and the market demand for energy supply.

The Russian part is recognized to be the largest among oil and gas resources owned by Arctic nations. However, scarce information and available geological data create uncertainty regarding a future role of the Russian Arctic as main base of energy supply in the second part of the XXI century. A further uncertainty is the pace at which production from northern areas including the Arctic will be brought onstream - either because of national policy, infrastructure development or investment by the state and the oil companies. These areas embrace those where development has already been started (Offshore Sakhalin, northern Timan Pechora) and those awaiting future involvement, like Barents and Pechora seas, East Siberia, Yamal, Kara Sea and Kamchatka.

Offhore production levels are likely to be very important to Russia in mid and long terms, especially as most (if not all) production will go for export and, in the process, open doors to new markets. In this way, offshore production will introduce a new and very significant component to Russia's export strategy. However, active involvement of the Russian Arctic resources in the global energy supply process needs a detailed analysis and clear understanding of the market potential for Russian gas and oil (required volumes, time frame, transportations routes) and requires close attention of the government to the most important issues that should be in place, like national standards and guidelines for Arctic resources development, stable, transparent and predictable law as a necessary precondition for massive investments in exploration and production and, not least, active involvement of foreign companies in development of Arctic resources that could bring along with investments an indispensible competence and experience, available technology and Health, Safety and Environment (HSE) principles.

Development of oil and gas fields in the arctic seas located few hundreds miles from shore is according to expert opinion the most challenging project in the world. Without international cooperation, coordination of all activities and use of modern and proven technologies for production of hydrocarbons, their transport, efficient safety and environmental protection tools the realization of such a project would be questionable.
\end{abstract}

\section{INTRODUCTION}

The Russian continental shelf constitutes $22 \%$ of the World Ocean shelf and amounts to 6.2 million $\mathrm{km}^{2}$ (among them 4.2 million $\mathrm{km}^{2}$ within the Economic zone). Arctic Ocean accumulates more than $50 \%$ of the sediment coming to the World Ocean, which explain intensive sedimentation processes in this region. It explains a high potential of the Arctic shelf in general and the Russian Arctic shelf, in particular.

In the global picture of traditional hydrocarbon resources $25 \%$ of them, or $c a .100$ Billion Tons of Oil Equivalent (BTOE), belong to the Russian Arctic [1]. There are quite few scenarios on how Russian arctic (conventional) resources can be developed, both at corporate and national levels generated by different companies, institutions and governmental bodies for different purposes, time frames and based on different assumptions. However, all estimates do have a common understanding that arctic petroleum resources are huge. The following example will help in understanding how big these resources are. Assuming that the Russian Arctic shelf's annual production will culminate at 400 million toe (approximately corresponding to the doubled the annual peak production from the Norwegian continental shelf) one comes to a conclusion that a sustainable production of petroleum from that area can be secured for more than hundred years.

Unconventional hydrocarbon resources of the Russian Arctic shelf (mainly, gas hydrates) accumulated under the sea bed are even higher, and their quantity can simply be estimated as "plenty". According to a forecast made by one of the gas hydrates discoverer Makogon by 2050 global methane production from gas hydrates may contribute with as much as $16 \%$ to the global energy supply [2]. However, extensive research is required to develop technology for methane production from gas hydrates.

Potential of arctic resources is associated not only with the opportunities but also with its development challenges. Many modern and conventional technologies cannot be used in the Arctic and there is a need for new concepts and new technologies that are efficient, cost effective and safe. 
Despite a common view on Arctic as a new petroleum mega basin of the future, very little is explored and known. Based on the scarce available data resource estimates made by different countries and organizations are different and sometimes even controversial. This advocates for more intensive and well-coordinated exploration and active collaboration between the Arctic nations. Development (of arctic resources) will depend on market conditions, technological innovation, and the sizes of undiscovered accumulations [3].

The Arctic attracts much public attention. Arctic is a perceived icon by the public, the last "island" of a pristine, absolute purity - implications on reputation in case of an unsafe and inefficient development can be devastating for any company and even a country.

\section{ARCTIC PETROLEUM RESOURCES EVALUATION}

Quite several sources provide a good overview of petroleum reserves, including conventional oil and gas, shale oil, oil sand and Natural Gas Liquids (NGLs). According to [4], the world proved oil reserves amount to 170 billion tons, and total proved gas reserves are equal to 185 Trillion Cubic Meters (TCM). In total proved petroleum reserves amount to 337 Billion Tons of Oil Equivalent (BTOE), which is enough for more than 45 years of continuous production with rate achieved by end 2008.

In the global picture, Russia is in 7th place in oil proved reserves with its 10.8 billion tons and takes a lead in proved gas reserves $(43.3 \mathrm{TCM})$ that is more than $23 \%$ of the world's total proved gas reserves. Huge gas accumulations enable Russia's first place in total proved oil and gas reserves with nearly 50 BTOE, closely followed by Iran and Saudi Arabia with their respective 45.5 and 43.1 BTOE.

In terms of petroleum resources the global picture is not that clear. Most geologists agree that the Arctic Ocean is the place with highest petroleum potential (Fig. 1). However, estimates are at big variance.

Being agreed on that they disagree on how much can be discovered and produced. There are very few estimates of global arctic petroleum potential available.

According to the Ministry of Natural Resources, in the global picture of traditional hydrocarbon resources $25 \%$ of them, or $c a .100$ Billion Tons of Oil Equivalent, belong to the Russian Arctic [1].

The Russian Academy of Sciences gives a total resource base of the Russian Arctic resources varying from $97 \mathrm{BTOE}$ $\left(\mathrm{P}_{90}\right.$ level) to $212 \mathrm{BTOE}\left(\mathrm{P}_{10}\right.$ level) with the best estimate of $142 \mathrm{BTOE}\left(\mathrm{P}_{50} \text { level }\right)^{1}[5]$. According to the same estimate, $68 \%$ of this amount, or 97 BTOE (best estimate), belong to the Russian Arctic offshore.

\footnotetext{
${ }^{1}$ The data shown here were recalculated from the original source data [5] with the levels of certainty $\mathrm{P}_{95}$ and $\mathrm{P}_{05}$.
}

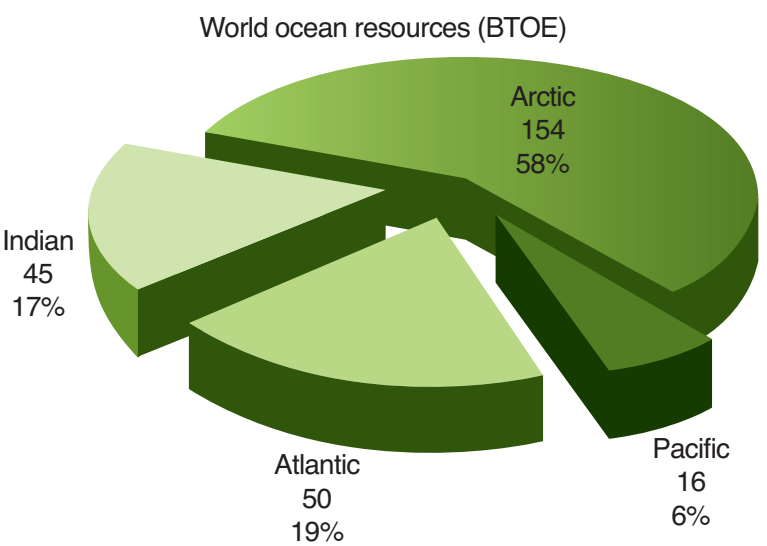

Figure 1

World ocean resources [5].

The USGS gives quite a different number. According to Gautier et al. [3], 66 BTOE of undiscovered, technically recoverable oil, gas \& NGLs in the whole Arctic, of which $84 \%$ are expected to occur offshore. Assuming that Russia's share of it is $70 \%$, its recoverable reserves are $46 \mathrm{BTOE}$, or approximately $78 \mathrm{BTOE}$ for resource base. This is $22 \%$ lower than estimates made by the Russian Ministry of Natural Resources, and almost twice as small as the best estimate of the Russian Academy of Sciences.

Figure 2 illustrates assessment of petroleum basins in circumpolar region, carried out by Belonin and Grigorenko [6].

In this report, recoverable quantities of conventional hydrocarbons in the circumpolar Arctic are estimated at 135 BTOE, where $25 \%$ belong to liquid hydrocarbons. Similar evaluation is given in the recently published text book on World ocean oil and gas resources [7].

Mapping of petroleum basins carried out in [6] looks similar to the results recently published by Gautier et al. [3], although estimates of technically recoverable hydrocarbon quantities quoted in both publications are two-fold different.

However, the authors of Reference [3] admit that "these first estimates are, in many cases, based on very scant geological information, and our understanding of Arctic resources will certainly change as more data become available".

For convenience, we mapped all referenced estimates in Figure 3.

Such a difference in the Arctic resources estimate has also another explanation. Lack of data gives a way to different suggestions and assumptions and an opportunity to use various approaches and types of the estimates, like deterministic, stochastic (Monte Carlo), fuzzy and interval evaluations of the in-place volumes. Similar approaches are used for evaluating technologically possible and economically feasible recoverable volumes, etc. 


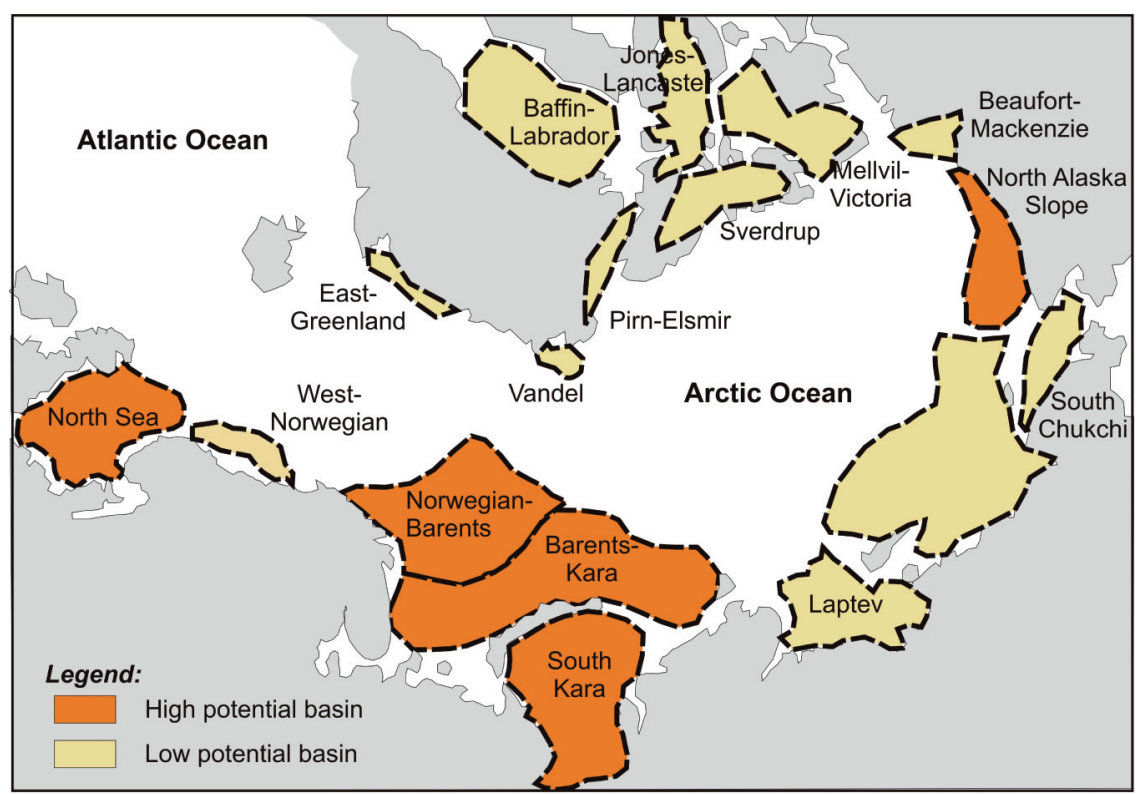

Figure 2

Circumpolar belt of hydrocarbon accumulation: 17 petroleum basins of Eurasia, North America and Greenland (redrawn from [6]).

Arctic resources and technically recoverable reserves (BTOE)

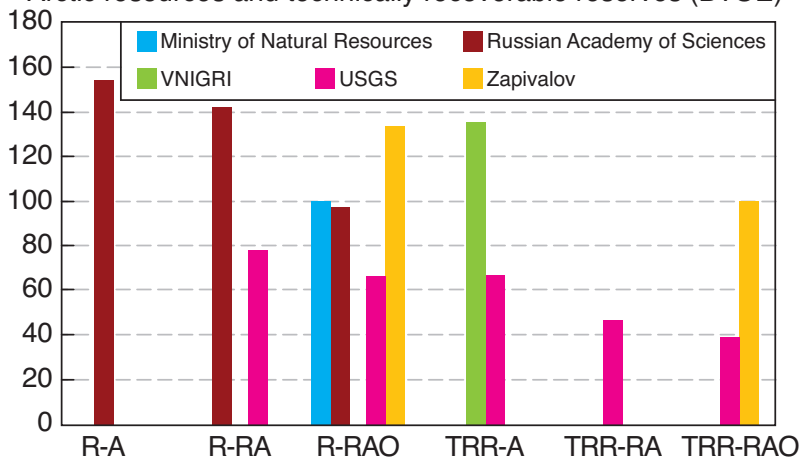

Legend:

First letter, R: resources; TRR: technically recoverable reserves; Second letters, A: the whole Arctic; RA: Russian Arctic; RAO: Russian Arctic Offshore.

Figure 3

Different estimates of Arctic resources and technically recoverable reserves.

Finally, due to a recent agreement on the border delimitation we can now consider a so-called "Grey zone" in a total picture of Arctic resources. Although these potential resources have been part of the total hydrocarbon evaluation, now they can be put on the map and can be considered for their active exploration and future development. Again, Russian and US estimates for this area are quite different (6.8 BTOE versus
1.7 BTOE, predominantly gas in both estimates). However, even the lowest estimate of USGS is somewhat 10 times greater than the total resource base of two prolific Norwegian areas Lofoten and Vesterålen.

In order to get a better picture of the available (Arctic) resources, an international cooperation is required. Recent agreement on the border delimitation in the Barents Sea between Norway and Russia spurred a new cooperation in Science and Engineering between the two countries that, most likely, will result in re-evaluation of hydrocarbon resources of the Barents Sea, their technically recoverable volumes, new offshore field development concepts, means and routes of transportation, types of products to be transported, etc.

\section{EXPLORATION STATUS OF THE RUSSIAN ARCTIC}

It is necessary to admit that the Russian arctic offshore areas are barely explored. Comparison with the Norwegian continental shelf shows that the exploration coverage (in $\mathrm{km}$ of seismic lines per $\mathrm{km}^{2}$ ) of the Russian northern seas is somewhat 20 times lower than that in Norway (Fig. 4). The number of exploration wells is $c a .25$ times lower than their number on the Norwegian continental shelf. However, exploration is a necessary step to convert enormous but yet hypothetical petroleum resources of the Russian Arctic to a reserve base that could be further developed and exploited.

Result of the exploration activities showed that the main part of forecasted resources in the North-Western part of the 

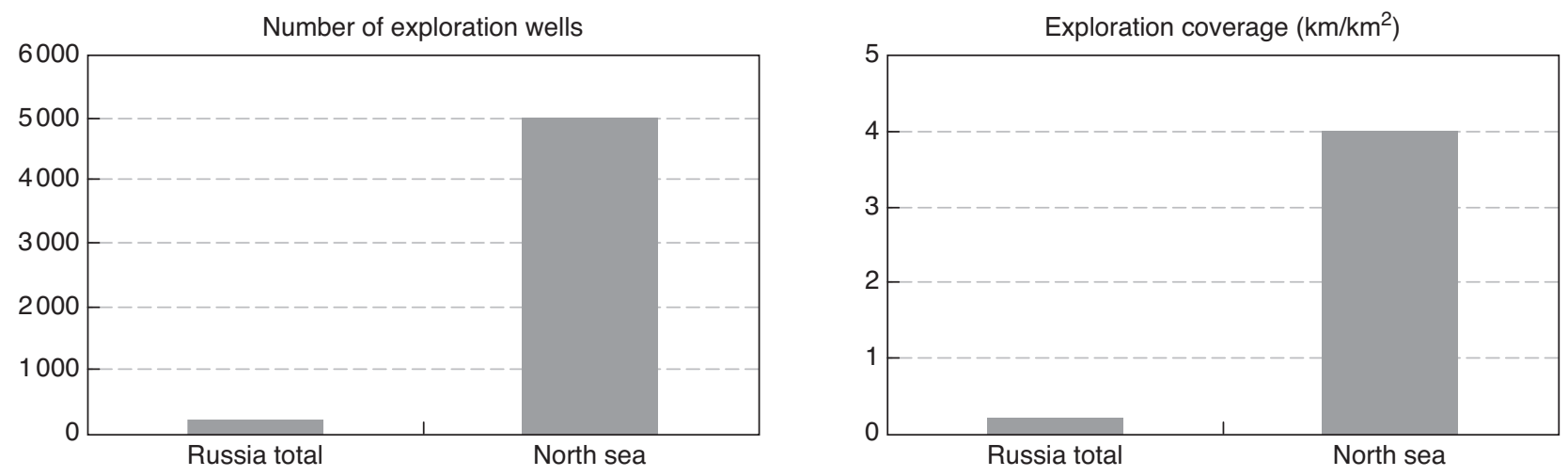

Figure 4

The Russian Arctic offshore and the Norwegian continental shelf.

Russian Arctic (categories $\mathrm{C}_{3}$ and $\mathrm{D}_{1}$, according to Russian classification) is concentrated in offshore areas with water depth 50-100 m and associated with sediments located 4-5 km below the sea bottom, i.e. technically accessible by drilling. In total, the distribution of potential and explored oil and gas resources of the Russian shelf, including Arctic, is presented in the table below.

TABLE 1

Distribution of potential and explored petroleum resources of the Russian shelves [8]

\begin{tabular}{|c|c|c|c|c|c|}
\hline \multirow[b]{2}{*}{ Region } & \multicolumn{2}{|c|}{ Potential resources (\%) } & \multicolumn{2}{|c|}{$\begin{array}{l}\text { Explored resources } \\
(\% \text { from total })\end{array}$} & \multirow{2}{*}{$\begin{array}{c}\text { Number of } \\
\text { discovered } \\
\text { oil } \\
\text { and gas fields }\end{array}$} \\
\hline & $\begin{array}{c}\text { Oil and } \\
\text { condensate }\end{array}$ & $\begin{array}{c}\text { Non- } \\
\text { associated } \\
\text { gas } \\
\end{array}$ & $\begin{array}{c}\text { Oil and } \\
\text { condensate }\end{array}$ & $\begin{array}{c}\text { Non- } \\
\text { associated } \\
\text { gas } \\
\end{array}$ & \\
\hline $\begin{array}{c}\text { Russian } \\
\text { Arctic } \\
\text { shelves }\end{array}$ & 100 & 100 & 3.4 & 9.1 & 24 \\
\hline $\begin{array}{l}\text { North-West } \\
\text { Russian } \\
\text { Arctic shelf }\end{array}$ & 86.1 & 88.3 & 1.1 & 8.4 & 9 \\
\hline
\end{tabular}

The data in the table shows that exploration degree of Arctic resources is extremely low: seismic coverage of offshore areas varies from 0.1 to $0.25 \mathrm{~km} / \mathrm{km}^{2}$. The number of exploration wells drilled offshore is unacceptably low: 1 well per $9000 \mathrm{~km}^{2}$ in Pechora Sea, 1 well per $27000 \mathrm{~km}^{2}$ in Barents Sea, and 1 well per $80000 \mathrm{~km}^{2}$ in Kara Sea. This exploration program was carried out according to a state program and enabled identification of a number of prospects although there further delineation and appraisal is pending.

According to information presented by CJSC "Sintezneftegaz" [9], it takes in average from 8 to 10 years to handle offshore exploration activities required by the state in order to submit all necessary documents to a State Committee on Reserves. Such a long time and cumbersome procedures reduce the willingness of potentially interested users of subsoil resources to exploration in new offshore areas, which has its negative impact on replacement of reserves.

According to the perspective planning by 2020 Russian shelf should annually produce $\mathrm{ca}$. 40 million tons of oil and around 220-230 BCM of gas. Such high levels of production can only be achieved by implementing active exploration program.

One of the indicators showing the wealth of a single company or the whole country is Reserve-to-Production ratio $(R / P$ ratio). $R / P$ ratio is defined as a ratio of reserves remaining at the end on any year divided by the production of that year; the result is the length of time that those remaining reserves would last if production were to continue at that rate [10].

Another important and very informative indicator on how secured is the reserve base and thus, future energy supply, is Reserve Replacement Ratio (RRR). It is defined as a ratio of incremental reserve growth to cumulative production over the same time period and is a key parameter in assessing how stable and continuous the future production and thus, the energy supply can be. It is obvious that for sustainable production growth RRR should be greater than one. However, in the Russian oil and gas industry RRR's trend is not very optimistic (Fig. 5).

Reserve replacement could be maintained by large scale projects in new regions of oil and gas production - Eastern Siberia, Far East and Arctic Shelf. However, long distances to market and lack of infrastructure make these projects not so attractive for a business. Development of resources of the northern seas is additionally complicated by the lack of 

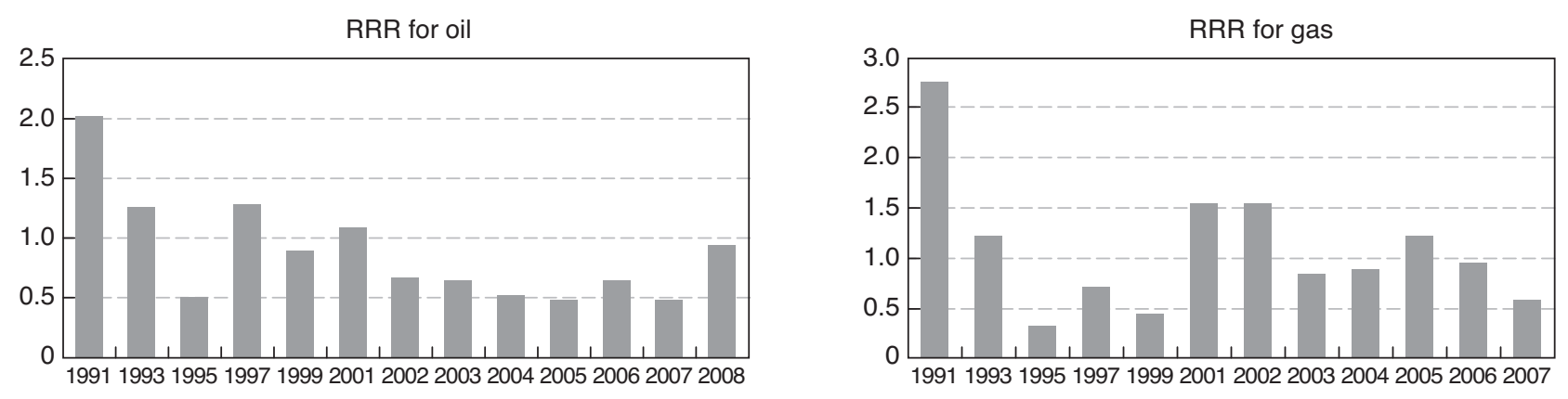

Figure 5

Replacement Ratio for oil and gas reserves in Russia.

technology and qualified personnel, operational and environmental challenges and even higher cost. In order to fulfill this task a state (coordinated) exploration program is required. It is also obvious that deployment of such a big and challenging project requires close cooperation of the international community.

\section{CURRENT ACTIVITY STATUS IN THE NORTH-WEST PART OF THE RUSSIAN ARCTIC}

There is a common view that shelves of the Barents, Kara and Pechora seas are considered as most prospective areas for offshore oil and gas field development.

At present, there are 5 fields discovered in the Barents Sea (Fig. 6): 2 gas-condensate fields (Shtokmanskoye and Ledovoye) and 3 gas fields (Ludlovskoye, Murmanskoye and North-Kildinskoye). Potentially, interesting structures are located in the Fersman-Demidov shoulder, Shatsky and Vernadsky swells, and also in the area of Medvezhy and Admiralteisky swells. The former "Grey zone" has a high potential in the area of Fedynsky Swell and East-Barents foredeep where quite a number of structures are very prospective for both gas and oil. Up to a present time, the oil has not being discovered in arctic seas except the Pechora Sea, therefore these locations including Admiralteisky swell are of particular interest.

It is anticipated that development of the Barents Sea will start from the Shtokman field, which later will be accompanied by satellite fields Ledovoye, Ludlovskoye and Terskoye and later by the fields of Fersman and Demidov swells. This concept will enable utilization of available infrastructure, which, in its turn, will reduce investments in the development project.

In the Kara Sea shelf (Fig. 7) prospective locations are Yamal shelf with its Leningradskoye and Rusanovskoye fields as well as aquatorial extension of Kharasaveyskoye and Kruzenshternskoye fields. Another attractive location is $\mathrm{Ob}$ (Severo-Kamennomysskoye, Kamennomysskoye-more and Obskoye fields, aquatorial extension of Yurkharovskoye, Salekhaptskoye, Yuzhno-Tambeiskoye, Utrennee and Tasiiskoye fields) and Tazov (Chugoriakhinskoye field and aquatorial extension of Semakovskoye, Antipayutinskoye and Tota-Yakhinskoye fields) bays.

According to the estimates, gas production from the Kara Sea shelf area may reach up to 200 billion $\mathrm{m}^{3}$ (BCM) annually, which can compensate the decline in production from fields in Yamal peninsula and enable utilization of available infrastructure. Gas fields of the $\mathrm{Ob}$ and Tazov bay area (Fig. 8)

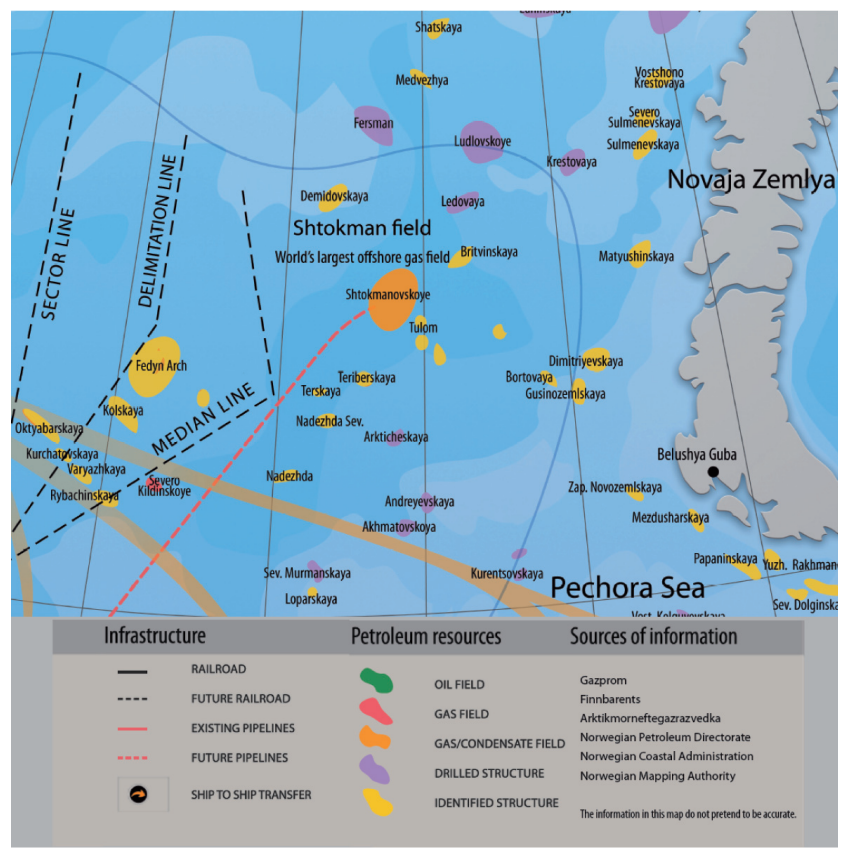

Figure 6

Barents Sea discoveries. Source: Sherpa Konsult (2010). Available at: www.sherpakonsult.com. 


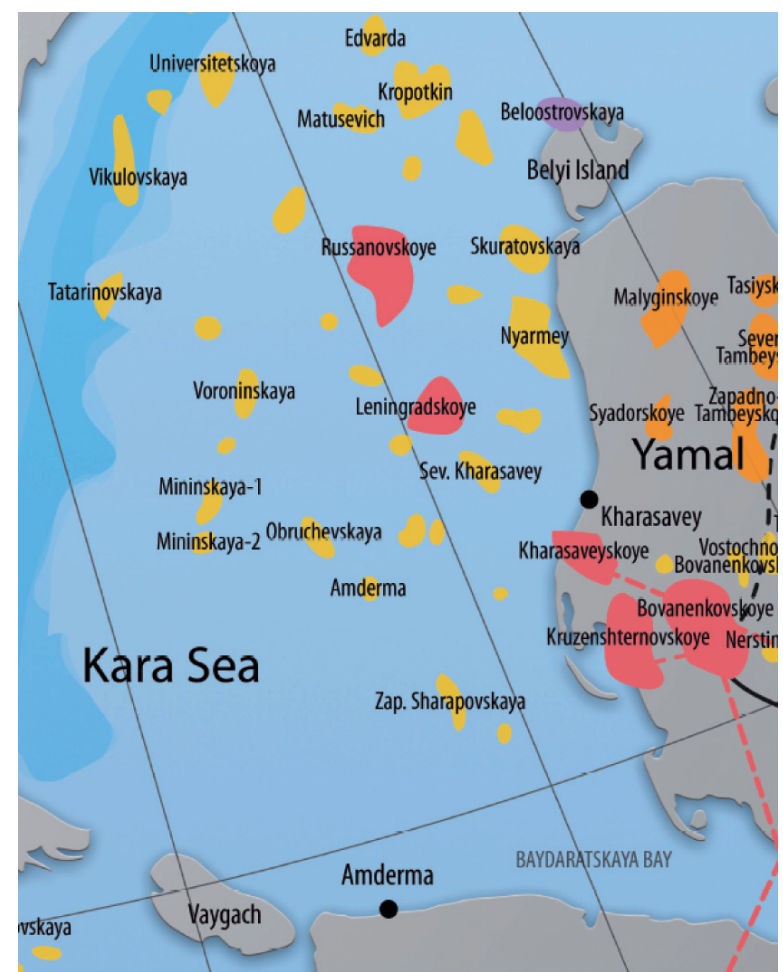

Figure 7

Kara Sea discoveries. Source: Sherpa Konsult (2010). Available at: www.sherpakonsult.com

could produce gas with the annual rate of $75 \mathrm{BCM}$. Shelf of the Pechora Sea (Fig. 9) is the only one among all arctic shelves that contain oil. The main fields of this region are Prirazlomnoye, Dolginskoye, Medyn-more, Varandey-more and Kolokomorskoye oil fields, Severo-Gulyaevskoye oilgas-condensate field and Pomorskoye gas-condensate field.

Besides these fields, there are several large and prospective structures located in the South-Eastern part of Pechora Sea: Yuzhno-Russkaya, Pakhanchevskaya, Sakhaninskaya and Papaninskaya. According to the estimates, total resources of Medyn-Varandey and Kolokomorsky locations amount to 410 million tons of oil with recoverable volume of 80 million tons. It is planned that Prirazlomnoye field will start the oil production in the Pechora Sea followed by other fields development.

\section{AGREEMENT ON THE BORDER DELIMITATION IN THE BARENTS SEA CAN SPUR FURTHER COOPERATION}

A strategic decision on delimitation of the border between Norway and Russia was awaited for a long time - nearly 40 years. It gives both countries a new opportunity for the sustainable exploration program in their respective waters

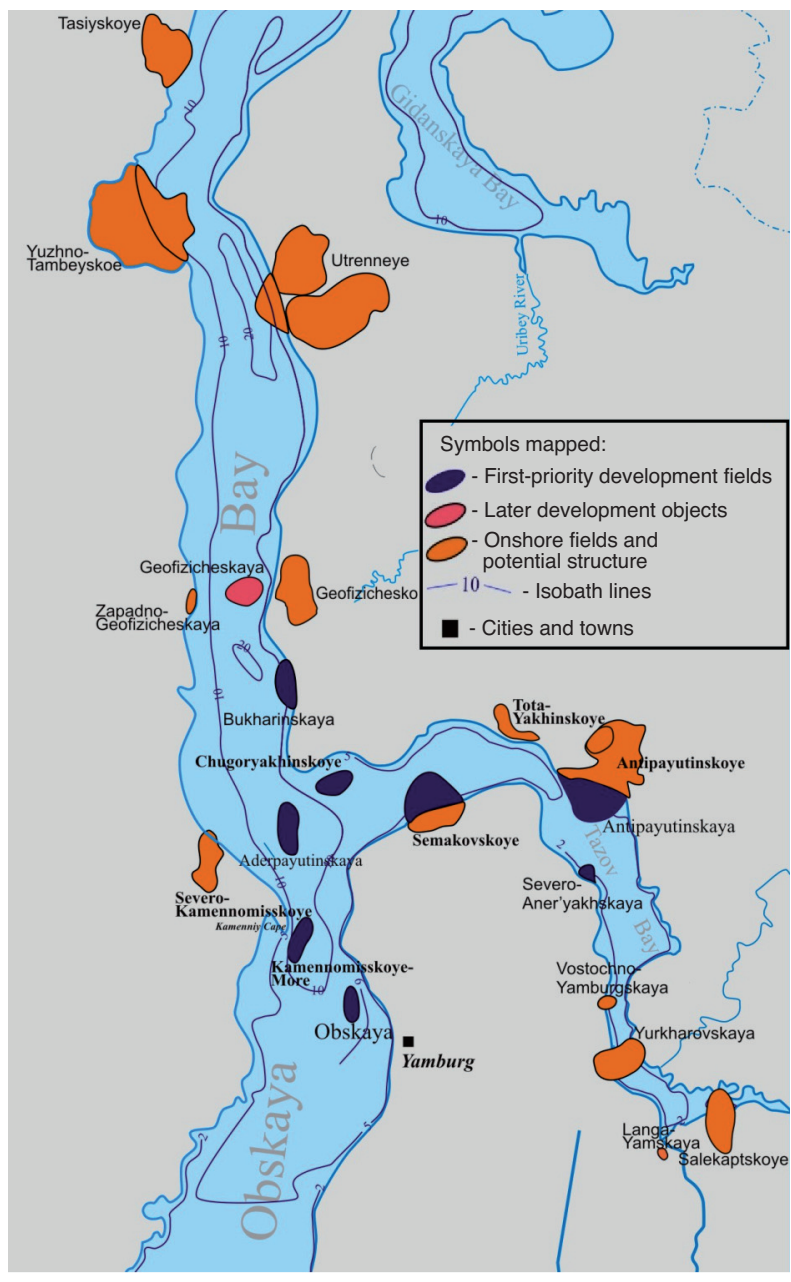

Figure 8

$\mathrm{Ob}$ and Tazov bays area.

and in the whole region. Moreover, this decision opens a new page of Russian-Norwegian cooperation, since it gives the legal basis for data exchange and the joint exploration program.

In the likely case of a cross-border discovery of hydrocarbons (in this area, most likely, gas) a unitization principle could be used, according to which a discovered field is treated as a single asset by neighboring countries that resulted in a win-win situation. This idea has been successfully employed in Norway, and Norwegian companies are very competent in exploiting this principle successfully.

Despite vast resources of oil and gas in the Arctic the question arises: do we need these resources? Today arctic gas is more expensive than traditional gas and even shale gas that recently emerged the market. However, continuous and steadily increasing market demand and its proximity to the shipping routes from the arctic seas, huge quantities of gas 


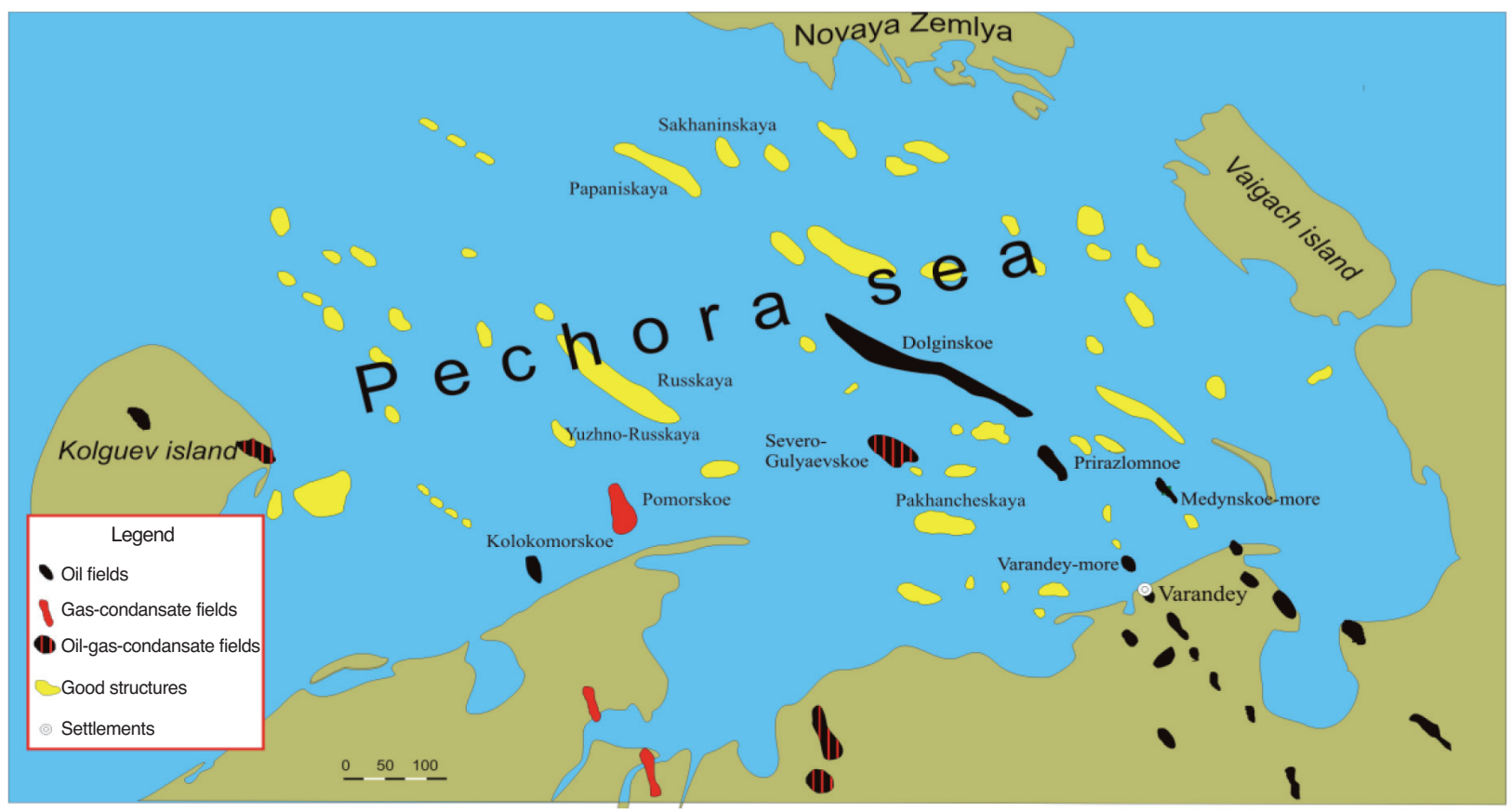

Figure 9

Pechora Sea discoveries.

under northern seas and, not the least, the growing competition between different primary energy sources are the strong motivations for technology development. Pretty soon demand for development in the Arctic will be high.

There is more than 1000 year peaceful coexistence between Norway and Russia. A good and fruitful cooperation up north, including coal mining and fishing in Spitsbergen has created a special friendly climate and trustworthy relations between the two nations. Such a solid cooperation between the two countries is a matter of benefits which it brings to them. A use of existing and well developed supply bases in Finnmark can, should and will be used in joint petroleum projects.

The Norwegian-Russian agreement on delimitation of the Barents Sea can spur a new round of active cooperation between two countries on the development of Arctic resources. New agreement opens the new opportunities for active cooperation in developing this strategically important region. The resolved zone is located closer to the shoreline than the Shtokman field, and this may facilitate a new concept of the whole Barents region development...

\section{CHALLENGES ASSOCIATED WITH ARCTIC RESOURCE DEVELOPMENT}

Along with the vast oil and gas resources of the Russian Arctic and opportunities associated with the development of
Arctic petroleum resources, there are obvious challenges, among which most important are:

- severe climate conditions;

- presence of ice;

- high cost;

- long distance export of oil and gas - additional heavy cost;

- lack of technology, competence and experience in Arctic offshore field development;

- deficit of qualified personnel;

- environmental risks, not yet fully understood;

- emergency response time.

Mineral reserve base replacement for sustainable production of hydrocarbons in Russia could be maintained by large scale projects in new oil and gas regions, like East Siberia, the Far East and Arctic offshore. Among them East Siberia is characterized by the highest reserve replacement factor, although capital investments there is almost twice bigger than in traditionally oil producing regions, which is explained by the lack of infrastructure and the distance to the market. For example, most of the fields in East Siberia are located thousands kilometers away from the export sea hubs and regional centers with their industrial infrastructure and personnel. For example, one of the key East Siberian projects, Vankor (developed by Rosneft) is located $1500 \mathrm{~km}$ from Krasnoyarsk, the main transportation hub in this region. Facility construction there is complicated by severe climatic conditions, and construction period is limited by $c a$. 100 days per year. 


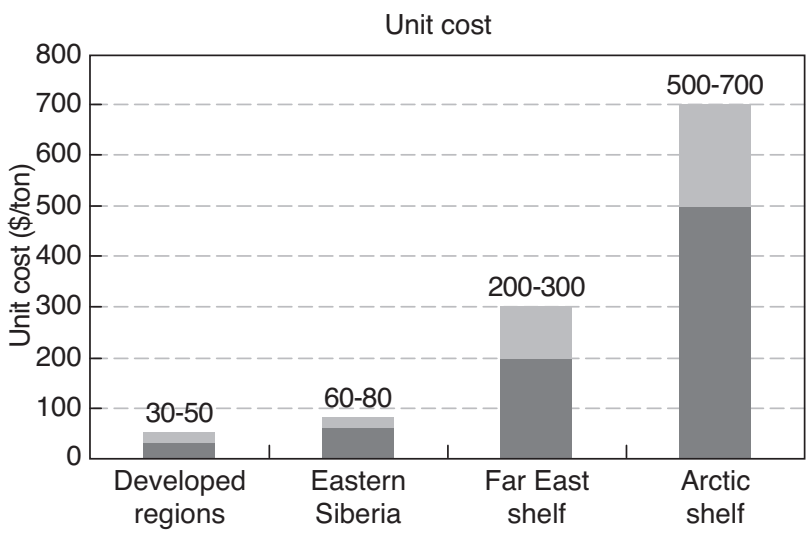

Figure 10

Unit cost development of oil and gas resources in various regions of Russian Federation.

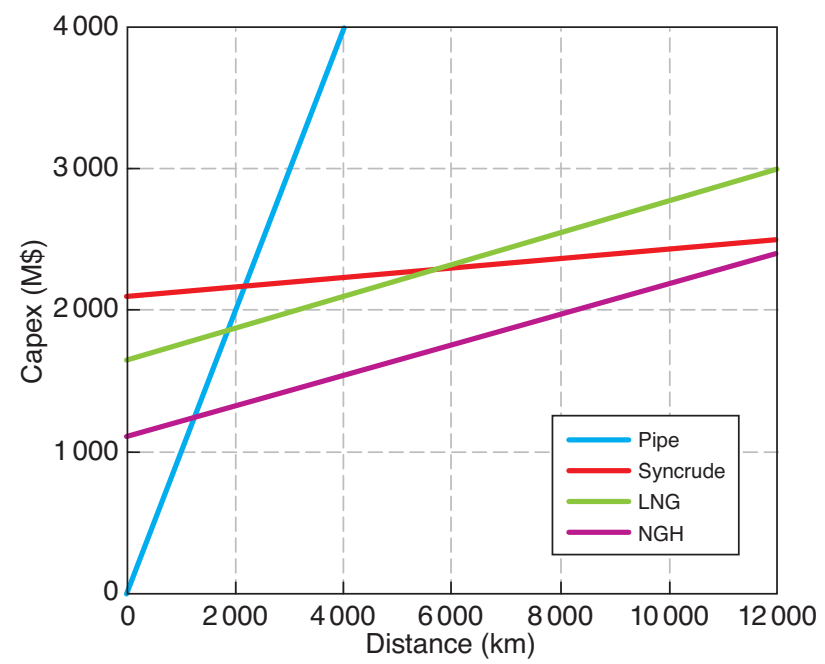

Figure 11

Opportunities for natural gas transportation (adapted from an estimate made by NTNU in 2002).

Lack of technologies and qualified personnel are additional factors that complicate development of the Arctic offshore fields to an even higher extent as compared to the East Siberian fields. Moreover, cost of development is believed to be even higher than in East Siberia (Fig. 10).

Recent estimates of the Russian Arctic Shelf development cost show the numbers close to $\$ 2.64$ trillion, of which $\$ 680$ billion should be invested in geological prospecting and $\$ 1.96$ trillion in development [11]. Our estimation shows that development of the Russian Arctic shelf according to Norwegian environmental and technology standards would require $c a$. $\$ 100-120$ billion per annum and could reach \$4-5 trillion by 2050 .

One of the challenges - additional heavy cost associated with long distance for oil and gas - can be reduced by utiliz- ing results of research. As shown in Figure 11, there are many options to transport oil, gas and their products from the development location to the market. As the distance increases the cost of transportation grows and some of the transportation means become more efficient than the others.

Another challenge is associated with the high cost of development in areas with limited or non-available infrastructure.

\section{MORE RESEARCH REQUIRED}

It is not only petroleum resources of the Arctic that are poorly explored. Our general knowledge of global ecosystems and the overall impact on them made by human activities is scarcely studied. There is very little knowledge on how human activities in offshore oil and gas resource development impact climate change in a long-term perspective. Humans have matured enough now to say confidently that we know virtually nothing about the impact we generate on the Earth. This is especially important for the vulnerable Arctic areas and northern seas.

Little knowledge exists on ice edge flora and fauna and fluctuations in abundances. Similar situation exists on ecotoxicity of Arctic species; data on non-Arctic species are not necessarily extrapolated. Lab facilities for eco-toxicity testing under Arctic conditions are scarce. Seabird migrations and their fluctuations due to climate change are not well understood. Biomarkers are needed to bridge the gap between risk assessment and monitoring.

More research on coastal and offshore flora and fauna is required. New regulations and environmental standards should be jointly developed by the international community. It would be advisable to organize a network (or a task force) of international institutions, organizations and qualified professionals who would develop the internationally recognized environmental standards and guidelines for activities in the vulnerable Arctic areas (northern seas and coastal zones). Active involvement of representatives of different industries involved in the development of such areas and their crossindustry communication would be highly recommended.

Activities conducted by universities throughout the world in the offshore oil and gas and environmental sector in the context of the International Polar Year (IPY) shall be applauded. These activities should have continuous support from the state and federal governments and should be converted into a truly international research program of global dimension.

\section{NEED FOR BETTER DECISIONS AND NEW TECHNOLOGIES FOR THE ARCTIC}

Another important part of the successful development of Arctic petroleum resources is skillful balancing of the 
needs of local stakeholders, business incentives, and the environment. Special attention and care should be paid for creating conditions for decent life of the indigenous people (Sami, Nenets, Inupiak). This goal can be achieved only by continuous dialogue with stakeholders regarding their habitat and their active involvement in the development and the timeline planning.

Regarding technologies one must admit that there are more challenges than available solutions that can be readily suggested and deployed for efficient and cost-effective development of the Arctic.

In order to overcome these challenges new and environmentally friendly technologies for Arctic conditions are required, among which most important, to our mind, are:

- stringent environmental standards for operations, technology, materials and equipment used in the Arctic regions. Standards developed by ISO should be at least referenced to the opinion of local stakeholders. However, the involvement of local stakeholders into a process of setting up the environmental standards seems more efficient;

- development of the new materials, equipment, installations for the whole value chain (exploration, drilling, production, processing and transportation) that can be reliable in the arctic conditions;

- safe operations in the Arctic with emphasis on evacuation of personnel in ice-infested waters;

- technology being in a fast developing track doesn't often meet the environmental standards (one example: there is still no solution for safe field development in shallow arctic waters);

- new solutions should be studied for the areas few hundred miles away from a shoreline. Waste management should be developed to a standard routine operation. Handling of produced and ballast water is still a big issue;

- an international program on oil spill response in iceinfested waters should be initiated as soon as possible. This is one of the biggest challenges in the safe operations in the Arctic. Establishment of international quick-reaction forces to combat oil spills;

- modeling and prediction of iceberg location and movement - an important element in safe development of the Arctic;

- development of new (and environmentally friendly) exploration technology - according to standards/guidelines from co-existing industry sectors (fishing, hunting, etc.);

- new technology for the offshore and coastal oil and gas field development - need for peaceful co-existence of different industry sectors.

The example from the Snøhvit gas-condensate field on the Norwegian continental shelf shows that nearly 18 years were spent on developing a new technology of the hydrocarbon field development (so-called sub-sea production technology) before it was finally accepted by the fishing industry and approved by the state. In 2007, a Norwegian state oil company Statoil set a very ambitious goal: by 2030 to excel technologies to such a level that to have the whole arctic offshore accessible for efficient and safe development. A previous record in developing technologies that can be "approved" by society for Snøhvit development gives a confidence that this new goal can also be achieved.

There is common understanding regarding the need for new technology. The following areas for technology development have been identified and are subject to extensive research [12]:

- Subsea drilling and production technology in the Arctic:

- drilling with riserless mud recovery system,

- zero discharge well test,

- subsea processing technology,

- subsea boosting, pumps and compressors,

- subsea electric power generation, transformation and distribution,

- subsea well intervention, ROV retrieval;

- Long distance transportation of oil, gas and condensate:

- riser and flow line hydrate,

- multiphase flow modeling,

- CNG, LNG and NGH (natural gas hydrates) transportation options versus subsea piped gas,

- fiscal wet gas monitoring;

- Petroleum exploitation and ice:

- ice resilient floater,

- sub-ice measurement and data collection;

- Barents Sea on screen: real time monitoring of northern oceanic areas:

- environmental data exchange and monitoring,

- reservoir monitoring,

- 3D modeling visualization;

- Common HSE practice:

- process qualification procedure.

\section{ROLE OF INTERNATIONAL COOPERATION IN OFFSHORE OIL AND GAS FIELD DEVELOPMENT}

Development of oil and gas field in the arctic seas located few hundred miles from shoreline is, according to expert opinion, the most challenging project in the world. Global challenges and common goals advocate for a broad international cooperation in developing Arctic resources and coordination of all activities. Without international cooperation, coordination of all activities and use of modern and proven technologies for production of hydrocarbons, their transport, efficient safety and environmental protection tools the realization of such project would be questionable. 


\section{ROLE OF UNIVERSITIES}

It is important to outline that international cooperation on research and the knowledge transfer across borders could actively be facilitated through university cooperation. There should be a well balanced proportion of studies related to fundamental research and immediate industrial needs (International graduate programs in Project Management, non-traditional sources of fossil fuels like gas hydrates, environmental studies, etc.). In particular, efforts relevant to International Polar Year (IPY) and follow-up efforts, in the content of international education and research needs for efficient offshore and coastal oil and gas development can serve as an example for organizing research and educational programs between universities.

International graduate and postgraduate programs as well as collaborative research projects can facilitate cross-border knowledge transfer and foster technology development in (not limited to) the following important areas:

- project planning, project management and project execution;

- industrial and environmental safety;

- uncertainty and risk in decision making;

- offshore oil and gas field development;

- transport of hydrocarbons and their products using Northern passages;

- development of non-traditional resources of fossil fuels (gas-hydrates, coal-bed methane) and technology for their efficient and cost-effective development;

- study of arctic ecosystem and its changes with the climate change (IPY Collaborative research);

- state of the Arctic sea ice cover (IPY Collaborative research);

- coastal infrastructure;

- indigenous knowledge (a possible joint project between US, Canada, Norway, Denmark and Russia).

Knowledge and competence accumulated in different parts of the globe should be a subject of experience transfer through university international cooperation. Internationalization of efforts in the development of arctic resources is the only way to do it in a sustainable, cost-effective and efficient way. International university collaboration in fulfilling this task is of paramount importance.

\section{CONCLUSION}

Do we have an alternative to the development of oil and gas fields located in the Arctic offshore areas? The development of Arctic resources is inevitable although there is no hurry in doing that now. Russia has abundant petroleum resources onshore with technology for safe and efficient development available now. There are two regions, namely, Nadym-Tazov and Krasnoyarsk regions that could easily replace development of the arctic resources of Yamal peninsula and the northern seas and maintain production at required level on a mid-term and even on a long-term basis.

The Nadym-Tazov region is a new hub of hydrocarbon accumulations in West Siberia. Recent estimates showed that this region has potential gas resources up to $20 \mathrm{TCM}$ [13]. Its proximity to the Yamburg gas condensate field with developed infrastructure and with gas pipeline exporting gas to Europe, makes development of this region very attractive both technologically and commercially. According to estimates made by VNIIGAZ a high level of production (up to $15 \mathrm{BCM}$ per year) can be reached already in the third year of development. According to the same analysis, such a project will require moderate (for that scale) capital investments with high internal rate of return (up to $30 \%$ ) in contrast to a $50 \%$ lower Shtokman's IRR.

The second potentially large center of petroleum production is associated with the Baikal region of hydrocarbons accumulation, which is accessible for industrial development. According to the resource evaluation carried out by Kontorovich et al. (2003), recoverable reserves of oil and gas in this region amount to 35-45 BTOE (approximately $30 \%$ of which are liquid hydrocarbons). The largest field of this region - Kovyktinskoye gas condensate field with estimated in-place volume of 2 TCM (our evaluation - up to $10 \mathrm{TCM}$ ) could serve as a starting point for this development.

As has been illustrated above, there are at least two alternatives to Shtokman and Yamal development in a mid- and even long-term. However, the future role of the Arctic region is of paramount importance, and its resources should be further explored and assessed and production - postponed until technology for environmentally safe and economically efficient development is in place.

\section{REFERENCES}

1 Dodin D.A., Ivanov V.L., Kaminsky V.D. (2008) The Russian Arctic: a vast oil and gas industry raw material base of the country, Litosfera J. 4, 76-92.

2 Makogon Y.F., Holditch S.A., Makogon T.Y. (2007). Natural gas-hydrates - A potential energy source for the 21st Century, $J$. Petrol.Sci.Eng. 56, 14-31.

3 Gautier D.L. et al. (2009) Assessment of Undiscovered Oil and Gas in the Arctic, Science 324, 1175 .

4 Zolotukhin A., Pflästerer H. (2007) Environmental challenges in the Arctic, Deep Offshore Technology (DOT) Conference, Stavanger, October 10-12.

5 Kontorovich A.E. (2009) Oil and gas resources and reserves of the Russian Arctic and the northern seas and the main tasks for their development, Russian Arctic Offshore (RAO) Conference, St. Petersburg, September 15-18.

6 Belonin M.D., Grigorenko Yu.N. (2007) Resource and geological analysis and the ways of development of offshore hydrocarbon resources, in Oil and Gas of the Arctic, Oil and Gas Publishing House, Moscow. 
7 Zapivalov N.P. (2009) World ocean oil and gas potential, Novosibirsk State University Publishing House, Novosibirsk, ISBN 978-5-94356-805-3.

8 Rabkin V.M., Mirzoev D.A., Karaev I.P. (2009) Key factors, affecting application of subsea technology in the Russian Arctic shelf, Gas Industry J. 07/634, 54-55.

9 Shelomentsev A.G., Khoshtaria V.N., Chursina N.V. (2006) Arctic shelf: time factor for realization of a license agreement at the exploration stage, Geology Geophysics Development Oil Gas Fields J. 1113-1117.

10 BP Statistical Review on World Energy (2009) Available at: www.bp.com/statisticalreview.
11 Skorlygina N. (2008) Sergey Bogdanchikov dived in a gold sea bottom, Kommersant, April 21, 1, 17 (in Russian).

12 Svein Bredahl (2007) DEMO 2000 - Achievements and Potential, Petroleum Technology Conference, Stavanger, January 12.

13 Gavrilov V.P. (2007) On expediency of accelerated development of hydrocarbon resources located in offshore Arctic and nearby zones, in Oil and Gas of the Arctic, Oil and Gas Publishing House, Moscow, pp. 343-351.

Final manuscript received in June 2011 Published online in December 2011 